\title{
EFEKTIVITAS MODEL PEMBELAJARAN KOOPERATIF
}

\author{
TIPE TWO STAY-TWO STRAY (TS-TS) DAN NUMBERED HEADS TOGETHER \\ (NHT) TERHADAP PRESTASI BELAJAR MATEMATIKA SISWA KELAS \\ VIII SMP DI KABUPATEN BANTUL \\ DITINJAU DARI AKTIVITAS BELAJAR
}

\author{
Davi Apriandi \\ FPMIPA IKIP PGRI Madiun
}

\begin{abstract}
ABSTRAK
Penelitian ini bertujuan untuk mengetahui: (1) manakah yang memberikan prestasi belajar lebih baik di antara pembelajaran dengan model kooperatif tipe TS-TS, model kooperatif tipe NHT atau pembelajaran konvensional, (2) manakah yang memberikan prestasi belajar lebih baik di antara siswa dengan aktivitas belajar tinggi, sedang atau rendah, (3) pada masing-masing tingkatan aktivitas belajar (tinggi, sedang, rendah), manakah yang memberikan prestasi belajar lebih baik di antara pembelajaran dengan model kooperatif tipe TS-TS, model kooperatif tipe NHT atau pembelajaran konvensional.

Penelitian ini termasuk penelitian eksperimental semu dengan desain faktorial 3x3. Populasi dalam penelitian ini adalah seluruh siswa kelas VIII Sekolah Menengah Pertama (SMP) Negeri Se-Kabupaten Bantul tahun pelajaran 2011/2012. Teknik pengambilan sampel dilakukan dengan cara stratified cluster random sampling. Banyaknya anggota sampel 268 siswa dengan 86 siswa untuk kelas eksperimen satu, 94 siswa untuk kelas eksperimen dua dan 88 siswa untuk kelas kontrol. Instrumen yang digunakan untuk mengumpulkan data adalah angket aktivitas belajar siswa dan tes prestasi belajar matematika. Uji coba instrumen angket meliputi validitas isi, konsistensi internal dan reliabilitas. Uji coba tes meliputi validitas isi, tingkat kesukaran, daya beda dan reliabilitas. Untuk uji coba normalitas menggunakan uji Lilliefors, uji homogenitas menggunakan uji Bartlett. Uji keseimbangan yang digunakan yaitu anava satu jalan dengan sel tak sama. Uji hipotesis penelitian menggunakan analisis variansi dua jalan dengan sel tak sama.

Dari hasil analisis diperoleh kesimpulan bahwa: (1) pembelajaran dengan model pembelajaran kooperatif tipe TS-TS memberikan prestasi belajar matematika yang sama dengan menggunakan pembelajaran kooperatif tipe NHT. Di sisi lain, prestasi belajar matematika siswa dengan model pembelajaran kooperatif tipe TS-TS dan kooperatif tipe NHT lebih baik dibandingkan dengan pembelajaran konvensional, (2) siswa dengan aktivitas belajar tinggi mempunyai prestasi belajar paling baik, sedangkan siswa yang mempunyai aktivitas belajar sedang lebih baik prestasinya daripada siswa dengan aktivitas belajar rendah, (3) prestasi belajar matematika siswa dengan model pembelajaran kooperatif tipe TS-TS, kooperatif tipe NHT dan konvensional memberikan hasil yang sama apabila diberikan pada siswa dengan aktivitas belajar tinggi atau rendah. Sedangkan pada aktivitas belajar sedang, prestasi belajar matematika siswa dengan model pembelajaran kooperatif tipe TS-TS dan kooperatif tipe NHT lebih
\end{abstract}


baik dibandingkan dengan pembelajaran konvensional dan prestasi belajar matematika siswa dengan model pembelajaran kooperatif tipe TS-TS dan kooperatif tipe NHT memberikan prestasi belajar yang sama.

Kata Kunci: Two Stay-Two Stray, Numbered Heads Together, Konvensional, Aktivitas Belajar.

\section{A. Pendahuluan}

Perkembangan pesat di bidang teknologi informasi dan komunikasi dewasa ini dilandasi oleh perkembangan matematika, sehingga untuk menguasai dan mencipta teknologi di masa depan diperlukan penguasaan matematika yang kuat sejak dini. Untuk itu pembelajaran matematika perlu diberikan kepada semua siswa mulai dari sekolah dasar untuk membekali peserta didik dengan kemampuan berpikir logis, analitis, sistematis, kritis, dan kreatif, serta kemampuan bekerjasama. Pembelajaran matematika harus dapat membuat siswa aktif dalam mempelajari materi pelajaran matematika. Siswa diharapkan dapat memahami konsep matematika dengan kemampuannya sendiri dan aktif dalam memecahkan masalah dari memahami masalah sampai mencari solusi tentang masalah tersebut. Dengan cara seperti itu, siswa mempunyai kemampuan bernalar secara logis dan kritis sehingga siswa cenderung lebih mudah memahami konsep matematika yang pada akhirnya akan berpengaruh terhadap prestasi belajar matematika.

Kenyataannya sampai saat ini matematika masih menjadi masalah bagi sebagian siswa. Kondisi itu terlihat dari hasil Ujian Nasional (UN) tahun 2009/2010 di Kabupaten Bantul. Hal ini dapat dilihat dari rata-rata hasil UN SMP/MTs tahun 2009/2010 pada mata pelajaran matematika sebesar 6,65. Selain itu, berdasarkan daftar persentase daya serap matematika UN SMP tahun 2009/2010 menunjukkan bahwa siswa masih kesulitan dalam menyelesaikan soal-soal tentang menerapkan konsep persamaan garis lurus. Hal tersebut terlihat dari daya serap siswa untuk 
menentukan gradien garis lurus dengan persamaan $\mathrm{ax}+\mathrm{by}+\mathrm{c}=0(\mathrm{a}, \mathrm{b}, \mathrm{c}$ bilangan bulat selain 1) sebesar 55,50\%, menentukan persamaan garis pada sebuah grafik sebesar 37,55\%, dan menentukan grafik dari persamaan suatu garis sebesar 41,99\%.

Dari data tersebut, terlihat bahwa penguasaan materi persamaan garis lurus tergolong rendah, artinya siswa masih belum memahami konsep materi persamaan garis lurus dengan baik. Pada materi tersebut terdapat berbagai ketentuan dan rumus untuk menentukan persamaan garis lurus. Oleh karena banyaknya materi itu maka siswa menjadi bingung dan akhirnya mereka hanya menghafal materi. Kemungkinan siswa merasa enggan harus memahami materi yang begitu banyak karena merasa tidak dilibatkan dalam proses pembelajaran. Akibatnya sering terjadi kesalahan konsep karena materi tidak benar-benar dipahami oleh siswa. Kesulitan yang dihadapi oleh siswa itu pada umumnya hanya disimpan sendiri tanpa dikomunikasikan dengan siswa lain atau guru sehingga kesulitan itu tidak dapat segera di atasi.

Rendahnya prestasi matematika pada materi persamaan garis lurus tidak terlepas dari peran guru. Salah satunya dipengaruhi oleh pemilihan model pembelajaran. Pemilihan dan penggunaan model pembelajaran yang tepat dapat mempengaruhi peningkatan prestasi belajar siswa, sedangkan pemakaian model pembelajaran yang kurang tepat dapat mengakibatkan siswa merasa malas dan bosan dalam mengikuti pelajaran, sehingga dapat mengakibatkan prestasi belajar yang dihasilkan kurang baik. Pembelajaran matematika cenderung masih berpusat pada guru dengan menerapkan strategi pembelajaran konvensional. Oleh karena itu, kemampuan serta kesiapan guru dalam pembelajaran memegang peranan penting bagi keberhasilan proses pembelajaran pada siswa. 
Selain itu, rendahnya prestasi belajar matematika juga dipengaruhi oleh faktor yang timbul dalam diri siswa, misalnya kecerdasan, minat, motivasi, aktivitas belajar, kemandirian belajar, kreativitas belajar, gaya belajar dan sebagainya. Salah satu faktor yang timbul dalam diri siswa adalah aktivitas belajar. Aktivitas belajar siswa merupakan salah satu indikator adanya keinginan siswa untuk belajar. Aktivitas belajar yang timbul dari siswa akan mengakibatkan pula terbentuknya pengetahuan dan keterampilan yang akan mengarah pada peningkatan prestasi.

Salah satu upaya untuk mengatasi kesulitan tersebut dan meningkatkan keberhasilan dalam pembelajaran matematika adalah dengan menerapkan model pembelajaran yang sesuai dengan teori pembelajaran konstruktivisme. Teori pembelajaran ini menganjurkan peran aktif siswa dalam pembelajaran, sedang peran guru adalah membantu siswa dalam menemukan fakta, konsep, atau prinsip, bukan mengendalikan seluruh kegiatan kelas. Diperlukan suatu model pembelajaran yang mampu membuat siswa aktif, saling berinteraksi, dan saling berdiskusi memecahkan masalah, sehingga siswa mampu membangun pengetahuannya sendiri. Salah satu model pembelajaran yang berlandaskan pada teori konstruktivisme adalah Cooperative Learning. Anita Lie (2008: 18) mendefinisikan bahwa Cooperative Learning merupakan sistem kerja/belajar kelompok yang terstruktur, yang termasuk di dalam struktur ini adalah saling ketergantungan positif, tanggung jawab individual, interaksi personal, keahlian bekerja sama, dan proses kelompok.

Salah satu model pembelajaran kooperatif adalah model pembelajaran kooperatif tipe Two Stay-Two Stray (TS-TS). Model pembelajaran ini terdiri dari tiga tahapan yaitu kerja kelompok, bertamu, dan laporan setelah bertamu. Dengan 
adanya tiga tahapan tersebut, siswa menjadi lebih aktif untuk memahami materi pelajaran. Siswa dapat berdiskusi dengan kelompok lainnya sehingga memperoleh lebih banyak masukan maupun kritikan. Dengan begitu siswa akan memperoleh lebih banyak pengetahuan. Selain model pembelajaran kooperatif tipe TS-TS, alternatif model pembelajaran yang dapat digunakan adalah model pembelajaran kooperatif tipe Numbered Heads Together (NHT). Adapun ciri khas dari NHT adalah guru hanya menunjuk seorang siswa yang mewakili kelompoknya. Dalam menunjuk siswa tersebut, guru tanpa memberi tahu terlebih dahulu siapa yang akan mewakili kelompok tersebut. Menurut Muhammad Nur (2005: 78), dengan cara tersebut akan menjamin keterlibatan total semua siswa dan merupakan upaya yang sangat baik untuk meningkatkan tanggung jawab individual dalam diskusi kelompok.

\section{B. Metode Penelitian}

1. Tempat dan waktu Penelitian

Penelitian dilaksanakan di SMP Negeri di Kabupaten Bantul pada semester gasal tahaun pelajaran 2011/2012.

2. Jenis Penelitian

Jenis penelitian ini adalah penelitian eksperimental semu (quasi eksperimental research).

3. Populasi dan Sampel Penelitian

Populasi dalam penelitian ini adalah seluruh siswa kelas VIII Sekolah Menengah Pertama (SMP) Negeri di Kabupaten Bantul tahun pelajaran 2011/2012. Pengambilan sampel dilakukan dengan cara stratified cluster 
random sampling. Cara pengambilan sampelnya yaitu dengan mengurutkan semua SMP Negeri di Kabupaten Bantul berdasarkan hasil Ujian Nasional pada mata pelajaran matematika tahun ajaran 2009/2010 dari yang tertinggi sampai yang terendah, kemudian membaginya berdasarkan kategori peringkat Ujian Nasional tinggi, peringkat Ujian Nasional sedang, dan peringkat Ujian Nasional rendah. Dari masing - masing kategori peringkat Ujian Nasional dipilih secara random satu sekolah. Selanjutnya dari masing - masing sekolah yang terpilih diambil secara random tiga kelas sebagai kelompok eksperimen 1, kelompok eksperimen 2 dan kelompok kontrol.

4. $\quad$ Metode Pengumpulan Data

Metode yang digunakan untuk memperoleh data adalah metode dokumentasi, metode angket dan metode tes. Metode dokumentasi digunakan untuk mengetahui daftar nama siswa dan nilai ulangan tengah semester matematika siswa kelas VIII tahun pelajaran 2011/2012. Metode angket digunakan untuk mengumpulkan data mengenai aktivitas belajar yang dimiliki siswa dan metode tes digunakan untuk memperoleh data atau mengukur prestasi belajar matematika pada materi persamaan garis lurus.

5. Teknik Analisi Data

Sebelum melakukan eksperimen, dilakukan uji keseimbangan terhadap kemampuan awal matematika menggunakan uji analisis variansi satu jalan dengan sel tak sama. Data prestasi belajar matematika dianalisis menggunakan analisis variansi dua jalan dengan sel tak sama. Sebelumnya, terhadap data kemampuan awal maupun data prestasi belajar dilakukan uji prasyarat meliputi uji normalitas populasi menggunakan metode Lilliefors 
dan uji homogenitas variansi populasi menggunakan metode Bartlett. Apabila hasil analisis variansi menunjukkan bahwa hipotesis nol ditolak, dilakukan uji komparasi ganda menggunakan metode Scheffe.

\section{Hasil Penelitian}

1. Uji Keseimbangan

Data yang digunakan untuk uji keseimbangan adalah nilai ulangan tengah semester pada materi sebelumnya dari tiga kelas pada masing-masing SMP Negeri yang terpilih pada setiap kategori peringkat Ujian Nasional di Kabupaten Bantul. Hasil uji prasyarat diperoleh kesimpulan bahwa sampel berasal dari populasi yang berdistribusi normal dan mempunyai variansi yang homogen. Hasil uji keseimbangan menggunakan uji analisis variansi satu jalan dengan sel tak sama terhadap data kemampuan awal matematika peserta didik diperoleh kesimpulan bahwa populasi mempunyai kemampuan awal matematika yang sama atau seimbang.

2. Uji Hipotesis

Data yang digunakan dalam pengujian hipotesis adalah data prestasi belajar matematika peserta didik pada materi pokok persamaan garis lurus. Hasil uji prasyarat diperoleh kesimpulan bahwa sampel berasal dari populasi yang berdistribusi normal dan mempunyai variansi yang homogen. Berikut disajikan hasil analisis variansi dua jalan dengan sel tak sama. 
Tabel 1. Rangkuman Analisis Variansi dua Jalan dengan Sel Tak Sama

\begin{tabular}{|l|c|c|c|c|c|c|}
\hline \multicolumn{1}{|c|}{ Sumber } & JK & $\mathrm{dk}$ & $\mathrm{RK}$ & $\mathrm{F}_{\text {hitung }}$ & $\mathrm{F}_{\text {tabel }}$ & $\begin{array}{c}\text { Keputusan } \\
\text { uji }\end{array}$ \\
\hline $\begin{array}{l}\text { Model } \\
\text { Pembelajaran } \\
\text { (A) }\end{array}$ & 5553,3796 & 2 & 2776,6898 & 14,9922 & 3,00 & $\mathrm{H}_{0 \mathrm{~A}}$ ditolak \\
\hline $\begin{array}{l}\text { Aktivitas } \\
\text { Belajar (B) }\end{array}$ & 13159,4950 & 2 & 6579,7475 & 35,5260 & 3,00 & $\mathrm{H}_{0 \mathrm{~B}}$ ditolak \\
\hline Interaksi (AB) & 2493,8785 & 4 & 623,4696 & 3,3663 & 2,37 & $\mathrm{H}_{0 \mathrm{AB}}$ ditolak \\
\hline Galat & 47969,1723 & 259 & 185,2092 & - & - & - \\
\hline Total & 69175,9255 & 267 & - & - & - & - \\
\hline
\end{tabular}

Dari hasil rangkuman analisis variansi dua jalan menunjukkan bahwa:

a. Model pembelajaran memberikan efek yang berbeda terhadap prestasi belajar siswa. Dengan kata lain, model pembelajaran kooperatif tipe TS-TS, pembelajaran kooperatif tipe NHT atau konvensional berpengaruh terhadap prestasi belajar siswa.

b. Aktivitas belajar memberikan efek yang berbeda terhadap prestasi belajar siswa. Dengan kata lain, aktivitas belajar tinggi, sedang, atau rendah berpengaruh terhadap prestasi belajar siswa.

c. Terdapat interaksi antara model pembelajaran dan aktivitas belajar terhadap prestasi belajar siswa. Dengan kata lain, pengaruh model pembelajaran terhadap prestasi belajar bergantung pada aktivitas belajar.

3. Uji Lanjut Pasca Anava

Berdasarkan hasil uji anava, keputusan uji $\mathrm{H}_{0 \mathrm{~A}}$ ditolak, $\mathrm{H}_{0 \mathrm{~B}}$ ditolak dan $\mathrm{H}_{0 \mathrm{AB}}$ ditolak untuk mengetahui kategori manakah yang membuat prestasi belajar siswa berbeda perlu dilakukan uji lanjut pasca anava. Metode yang digunakan pada uji lanjut pasca ANAVA adalah metode Scheffe. 
a. Karena $\mathrm{H}_{0 \mathrm{~A}}$ ditolak, maka perlu dilakukan komparasi rerata antar baris. Berikut rangkuman komparasi rerata antar baris:

Tabel 2. Rangkuman komparasi rerata antar baris

\begin{tabular}{|c|c|c|c|c|c|}
\hline No. & $\mathrm{H}_{0}$ & $\mathrm{~F}_{\text {hitung }}$ & 2.F $_{0,05 ; 2 ; 259}$ & $\mathrm{DK}$ & $\begin{array}{c}\text { Keputusan } \\
\text { Uji }\end{array}$ \\
\hline 1). & $\mu_{1 .}=\mu_{2 .}$ & 5,2146 & 6 & $\{\mathrm{~F} \mid \mathrm{F}>6\}$ & $\mathrm{H}_{0}$ diterima \\
\hline 2$).$ & $\mu_{1 .}=\mu_{3 .}$ & 38,5154 & 6 & $\{\mathrm{~F} \mid \mathrm{F}>6\}$ & $\mathrm{H}_{0}$ ditolak \\
\hline 3$).$ & $\mu_{2 .}=\mu_{3 .}$ & 16,3772 & 6 & $\{\mathrm{~F} \mid \mathrm{F}>6\}$ & $\mathrm{H}_{0}$ ditolak \\
\hline
\end{tabular}

Dari rangkuman komparasi rerata antar baris pada Tabel 2 diperoleh hasil sebagai berikut:

1) Model pembelajaran kooperatif tipe TS-TS memberikan prestasi belajar yang sama dengan model pembelajaran kooperatif tipe NHT.

2) Model pembelajaran kooperatif tipe TS-TS berbeda prestasi belajarnya dengan pembelajaran konvensional. Apabila dilihat rerata marginal prestasi belajar matematika siswa dari masing-masing model pembelajaran tersebut menunjukkan bahwa rerata model pembelajaran kooperatif tipe TS-TS sebesar 59,4884 dan rerata pembelajaran konvensional sebesar 46,6818. Karena rerata untuk model pembelajaran kooperatif tipe TS-TS lebih tinggi dibandingkan dengan pembelajaran konvensional maka diperoleh kesimpulan bahwa model pembelajaran kooperatif tipe TS-TS memberikan prestasi belajar yang lebih baik dibandingkan dengan pembelajaran langsung.

3) Model pembelajaran kooperatif tipe NHT berbeda prestasi belajarnya dengan pembelajaran konvensional. Apabila dilihat rerata marginal prestasi belajar matematika siswa dari masing-masing model pembelajaran tersebut menunjukkan bahwa rerata model pembelajaran kooperatif tipe 
NHT sebesar 54,8511 dan rerata pembelajaran konvensional sebesar 46,6818. Karena rerata untuk model pembelajaran kooperatif tipe NHT lebih tinggi dibandingkan dengan pembelajaran konvensional maka diperoleh kesimpulan bahwa model pembelajaran kooperatif tipe NHT memberikan prestasi belajar yang lebih baik dibandingkan dengan pembelajaran langsung.

b. Karena $\mathrm{H}_{0 \mathrm{~B}}$ ditolak, maka perlu dilakukan komparasi rerata antar kolom. Berikut rangkuman komparasi rerata antar kolom:

Tabel 3. Rangkuman komparasi rerata antar kolom

\begin{tabular}{|c|c|c|c|c|c|}
\hline No. & $\mathrm{H}_{0}$ & $\mathrm{~F}_{\text {hitung }}$ & $2 . \mathrm{F}_{(0,05 ; 2 ; 259)}$ & $\mathrm{DK}$ & $\begin{array}{c}\text { Keputusan } \\
\text { Uji }\end{array}$ \\
\hline 1). & $\mu_{.1}=\mu_{.2}$ & 20,3526 & 6 & $\{F \mid F>6\}$ & $\mathrm{H}_{0}$ ditolak \\
\hline 2). & $\mu_{.1}=\mu_{.3}$ & 72,2430 & 6 & $\{F \mid F>6\}$ & $\mathrm{H}_{0}$ ditolak \\
\hline 3$).$ & $\mu_{.2}=\mu_{.3}$ & 17,5073 & 6 & $\{F \mid F>6\}$ & $\mathrm{H}_{0}$ ditolak \\
\hline
\end{tabular}

Dari rangkuman komparasi rerata antar baris pada Tabel 3 diperoleh hasil sebagai berikut:

1) Siswa dengan aktivitas belajar tinggi berbeda prestasi belajarnya dengan siswa yang mempunyai aktivitas belajar sedang. Apabila dilihat rerata marginal prestasi belajar siswa dari masing-masing aktivitas belajar tersebut menunjukkan bahwa rerata aktivitas tinggi sebesar 62,6824 dan rerata aktivitas sedang sebesar 53,5158. Karena rerata untuk aktivitas belajar tinggi lebih tinggi dibandingkan dengan aktivitas belajar sedang maka diperoleh kesimpulan bahwa siswa dengan aktivitas belajar tinggi mempunyai prestasi belajar yang lebih baik dibandingkan dengan siswa yang mempunyai aktivitas belajar sedang.

2) Siswa dengan aktivitas belajar tinggi berbeda prestasi belajarnya dengan siswa yang mempunyai aktivitas belajar rendah. Apabila dilihat rerata 
marginal prestasi belajar siswa dari masing-masing aktivitas belajar tersebut menunjukkan bahwa rerata aktivitas tinggi sebesar 62,6824 dan rerata aktivitas rendah sebesar 45,0909. Karena rerata untuk aktivitas belajar tinggi lebih tinggi dibandingkan dengan aktivitas belajar rendah maka diperoleh kesimpulan bahwa siswa dengan aktivitas belajar tinggi mempunyai prestasi belajar yang lebih baik dibandingkan dengan siswa yang mempunyai aktivitas belajar rendah.

3) Siswa dengan aktivitas belajar sedang berbeda prestasi belajarnya dengan siswa yang mempunyai aktivitas belajar rendah. Apabila dilihat rerata marginal prestasi belajar siswa dari masing-masing aktivitas belajar tersebut menunjukkan bahwa rerata aktivitas sedang sebesar 53,5158 dan rerata aktivitas rendah sebesar 45,0909. Karena rerata untuk aktivitas belajar sedang lebih tinggi dibandingkan dengan aktivitas belajar rendah maka diperoleh kesimpulan bahwa siswa dengan aktivitas belajar sedang mempunyai prestasi belajar yang lebih baik dibandingkan dengan siswa yang mempunyai aktivitas belajar rendah.

c. Karena $\mathrm{H}_{0 \mathrm{AB}}$ ditolak, maka perlu dilakukan komparasi rerata antar sel. Pada penelitian ini hanya dilakukan komparasi rerata antar sel pada kolom yang sama. Berikut rangkuman komparasi rerata antar sel pada kolom yang sama:

Tabel 4. Rangkuman komparasi rerata antar sel pada kolom yang sama

\begin{tabular}{|c|c|c|c|c|c|}
\hline No. & $\mathrm{H}_{0}$ & $\mathrm{~F}_{\mathrm{obs}}$ & $8 . \mathrm{F}_{0,05 ; 8 ; 259}$ & $\mathrm{DK}$ & Keputusan Uji \\
\hline 1). & $\mu_{11}=\mu_{21}$ & 1,2344 & 15,52 & $\{F \mid F>15,52\}$ & $\mathrm{H}_{0}$ diterima \\
\hline 2). & $\mu_{11}=\mu_{31}$ & 3,4301 & 15,52 & $\{F \mid F>15,52\}$ & $\mathrm{H}_{0}$ diterima \\
\hline 3$).$ & $\mu_{21}=\mu_{31}$ & 0,7280 & 15,52 & $\{F \mid F>15,52\}$ & $\mathrm{H}_{0}$ diterima \\
\hline 4$).$ & $\mu_{12}=\mu_{22}$ & 0,5932 & 15,52 & $\{F \mid F>15,52\}$ & $\mathrm{H}_{0}$ diterima \\
\hline 5$).$ & $\mu_{12}=\mu_{32}$ & 38,8344 & 15,52 & $\{F \mid F>15,52\}$ & $\mathrm{H}_{0}$ ditolak \\
\hline
\end{tabular}




\begin{tabular}{|c|c|c|c|c|c|}
\hline 6$).$ & $\mu_{22}=\mu_{32}$ & 24,6422 & 15,52 & $\{F \mid F>15,52\}$ & $\mathrm{H}_{0}$ ditolak \\
\hline \hline 7$).$ & $\mu_{13}=\mu_{23}$ & 0,2871 & 15,52 & $\{F \mid F>15,52\}$ & $\mathrm{H}_{0}$ diterima \\
\hline 8$).$ & $\mu_{13}=\mu_{33}$ & 2,1001 & 15,52 & $\{F \mid F>15,52\}$ & $\mathrm{H}_{0}$ diterima \\
\hline 9$).$ & $\mu_{23}=\mu_{33}$ & 1,1276 & 15,52 & $\{F \mid F>15,52\}$ & $\mathrm{H}_{0}$ diterima \\
\hline
\end{tabular}

Dari rangkuman komparasi rerata antar sel pada kolom yang sama pada

Tabel 4 diperoleh hasil sebagai berikut:

a. Pada aktivitas belajar tinggi, model pembelajaran kooperatif tipe TS-TS dan model pembelajaran kooperatif tipe NHT memberikan prestasi belajar yang sama.

b. Pada aktivitas belajar tinggi, model pembelajaran kooperatif tipe TS-TS dan pembelajaran konvensional memberikan prestasi belajar yang sama.

c. Pada aktivitas belajar tinggi, model pembelajaran kooperatif tipe NHT dan pembelajaran konvensional memberikan prestasi belajar yang sama.

d. Pada aktivitas belajar sedang, model pembelajaran kooperatif tipe TS-TS dan model pembelajaran kooperatif tipe NHT memberikan prestasi belajar yang sama.

e. Pada aktivitas belajar sedang, model pembelajaran kooperatif tipe TS-TS berbeda prestasi belajarnya dengan pembelajaran konvensional. Apabila dilihat rerata marginal prestasi belajar matematika siswa dari masing-masing model pembelajaran tersebut menunjukkan bahwa rerata model pembelajaran kooperatif tipe TS-TS sebesar 63,4483 dan rerata pembelajaran konvensional sebesar 43,0698. Karena rerata model pembelajaran kooperatif tipe TS-TS lebih tinggi dibandingkan dengan pembelajaran konvensional maka diperoleh kesimpulan bahwa model pembelajaran kooperatif tipe TS-TS memberikan 
prestasi belajar yang lebih baik dibandingkan dengan pembelajaran konvensional.

f. Pada aktivitas belajar sedang, model pembelajaran kooperatif tipe NHT berbeda prestasi belajarnya dengan pembelajaran konvensional. Apabila dilihat rerata marginal prestasi belajar matematika siswa dari masing-masing model pembelajaran tersebut menunjukkan bahwa rerata model pembelajaran kooperatif tipe NHT sebesar 60,5214 dan rerata pembelajaran konvensional sebesar 43,0698. Karena rerata model pembelajaran kooperatif tipe NHT lebih tinggi dibandingkan dengan pembelajaran konvensional maka diperoleh kesimpulan bahwa model pembelajaran kooperatif tipe NHT memberikan prestasi belajar yang lebih baik dibandingkan dengan pembelajaran konvensional.

g. Pada aktivitas belajar rendah, model pembelajaran kooperatif tipe TS-TS dan model pembelajaran kooperatif tipe NHT memberikan prestasi belajar yang sama.

h. Pada aktivitas belajar rendah, model pembelajaran kooperatif tipe TS-TS dan pembelajaran konvensional memberikan prestasi belajar yang sama.

i. Pada aktivitas belajar rendah, model pembelajaran kooperatif tipe NHT dan pembelajaran konvensional memberikan prestasi belajar yang sama.

\section{Kesimpulan}

1. Pembelajaran dengan model pembelajaran kooperatif tipe Two Stay-Two Stray (TS-TS) memberikan prestasi belajar matematika yang sama dengan menggunakan pembelajaran kooperatif tipe Numbered Heads Together (NHT). Di 
sisi lain, prestasi belajar matematika siswa dengan model pembelajaran kooperatif tipe TS-TS dan kooperatif tipe NHT lebih baik dibandingkan dengan pembelajaran konvensional.

2. Siswa dengan aktivitas belajar tinggi mempunyai prestasi belajar paling baik, sedangkan siswa yang mempunyai aktivitas belajar sedang lebih baik prestasinya daripada siswa dengan aktivitas belajar rendah

3. Prestasi belajar matematika siswa dengan model pembelajaran kooperatif tipe Two Stay-Two Stray (TS-TS), kooperatif tipe Numbered Heads Together (NHT) dan konvensional memberikan hasil yang sama apabila diberikan pada siswa dengan aktivitas belajar tinggi atau rendah. Sedangkan pada aktivitas belajar sedang, prestasi belajar matematika siswa dengan model pembelajaran kooperatif tipe TS-TS dan kooperatif tipe NHT lebih baik dibandingkan dengan pembelajaran konvensional dan prestasi belajar matematika siswa dengan model pembelajaran kooperatif tipe TS-TS dan kooperatif tipe NHT memberikan prestasi belajar yang sama.

\section{E. Daftar Pustaka}

Anita Lie. 2008. Cooperative Learning: Mempraktikkan Cooperative Learning di Ruang-Ruang Kelas. Jakarta: PT. Grasindo.

Arends, R. I. 2004. Classroom Instruction and Management. New York: Mc. Grow Hill Book Co.

Budiyono. 2003. Metodologi Penelitian Pendidikan. Surakarta: UNS Press. . 2004. Statistika untuk Penelitian. Surakarta: UNS Press.

Etin Solihatin dan Raharjo. 2007. Cooperative Learning Analisis Model Pembelajaran IPS. Jakarta: Bumi Aksara. 
Sardiman, A. M. 2009. Interaksi dan Motivasi Belajar Mengajar. Jakarta : Rajawali Pers.

Slameto. 2003. Belajar dan Faktor-Faktor yang Mempengaruhinya. Jakarta: Rineka Cipta.

Slavin, R. E. 2008. Cooperative Learning. Diterjemahkan oleh Lita. Bandung: Nusa Media.

Stahl, R. E. 1994. Cooperative Learning Social Snabes. New York: Addison Wesly.

Syaiful Sagala. 2006. Konsep dan Makna Pembelajaran: untuk Membantu Memecahkan Problematika Belajar Mengajar. Bandung: Alfabeta.

Yatim Riyanto. 2009. Paradigma Baru Pembelajaran: Sebagai Referensi bagi Pendidik dalam Implementasi Pembelajaran yang Efektif dan Berkualitas. Jakarta.: Prenada Media. 